\title{
Pelatihan Dan Pendampingan Pembuatan Proposal Pengajuan Kredit Bank Bagi Para Pedagang Pasar Tradisonal Sukawinatan Palembang
}

\author{
Jusmawi Bustan \\ bayazmi@yahoo.co.id \\ Divianto \\ divi.kardin@gmail.com \\ Heri Setiawan \\ heri.setiawan@polsri.ac.id \\ Politeknik Negeri Sriwijaya
}

Diserahkan: 20 Juli 2017, Direvisi: 30 Juli 2017 Disetujui: 20 Agustus 2017

\begin{abstract}
Abstrak
Tujuan dari kegiatan pengabdian kepada masyarakat ini adalah untuk memberikan pelatihandan pendampingan pembuatan proposal pengajuan kredit bank kepada para pedagang UMKM di Pasar Tradisonal Suwawinatan. Permasalahan mitra yang diidentifikasi adalah banyak pedagang atau pelaku UMKM tersebut yang mengeluhkan mengenai ketidaktahuan atau ketidakpahaman mereka tentang proposal pengajuan kredit mikro ke bank. Mereka juga kurang tahu bagaimana pengembangan usaha dan manajemen permodalan yang baik. Hal ini dikarenakan latar belakang pendidikan dan kurangnya informasi yang mereka terima. Prioritas permasalahan yang akan dipecahkan solusinya adalah melalui metode pelatihan dan pendampingan pembuatan proposal pengajuan kredit bank. Disamping itu, memberikan penyuluhan mengenai pengembangan usaha dan manajemen permodalan. Kegiatan pelatihan dan pendampingan pembuatan proposal pengajuan kredit bank bagi para pedagang yang juga sekaligus pelaku atau pemilik UMKM Pasar Tradisional Sukawinatan dilaksanakan sesuai dengan apa yang diharapkan. Walaupun hasil tingkat pemahaman dan praktik dari 16 peserta aktif masih dalam skala 71\%-80,99\%, maka kegiatan pengabdian masyarakat ini dinyatakan "cukup baik" dan tersedia 4 proposal pengajuan kredit bank dari hasil kegiatan pendampingan.
\end{abstract}

Kata Kunci : Proposal, Pengajuan Kredit, Bank, Pedagang, UMKM

\begin{abstract}
The purpose of this community service is to provide coaching and assistance in making bank loan proposal to the traders of SMEs in Suwawinatan Traditional Market. The identified partner problem is that many traders or SMEs are complaining about their ignorance or lack of understanding about the proposal to apply for micro credit to the bank. They also do not know how good business development and capital management. This is due to educational background and lack of information they receive. The priority of problems to be solved is through the method of training and assistance in making bank loan proposal. In addition, provide information about business development and capital management. Training activities and assistance for the submission of bank credit proposal for the traders who are also the perpetrators or owners of SMEs Sukawinatan Traditional Market implemented in accordance with what is expected. Although the results of the level of understanding and practice of 16 active participants are still in the scale of $71 \%$ $80.99 \%$, then the community service activities are stated "good enough" and available 4 proposals for bank credit from the results of mentoring activities.
\end{abstract}

Keywords: Proposal, Submission of Credit, Bank, Trader, UMKM

\section{A. PENDAHULUAN \\ Latar Belakang}

Masyarakat sangat familiar dengan pasar tradisional yang merupakan denyut nadi ekonomi rakyat sebagai tempat bertemunya penjual dan pembeli yang ditandai dengan 
transaksi penjual pembeli secara langsung. Pasar tradisional yang terdapat di daerahdaerah pelosok sering disebut atau dikenal dengan "Kalangan" karena tidak dibuka setiap hari akan tetapi hari-hari tertentu saja setiap minggunya. Oleh karena, jutaan bahkan triliunan rupiah beredar di sana. Pasar tradisonal merupakan tempat yang tidak pernah sepi bahkan sebagian besar orang di Palembang memilih tempat tersebut untuk berbelanja. Namun sayangnya citra pasar tradisional kurang baik di masyarakat. Ungkapan pasar tradisional sebagai tempat yang kumuh, semrawut, becek, kotor, macet, dan minimnya fasilitas seperti terbatasnya tempat parkir, tempat sampah yang bau dan kotor, lorong yang sempit dan sebagainya. Pengembangan pasar baru yang dilakukan oleh Pemerintah Kota Palembang yakni di kawasan Gandus, Jakabaring, Kertapati, Talang Jambi, Sako Dalam, Poligon, Sukawinatan, Talang Kelapa Dalam, dan Kalidoni. Revitalisasi merupakan salah satu komitmen pemerintah dalam meningkatkan pelayanan pasar di Kota Palembang, akan tetapi, upaya ini belum bisa sepenuhnya dilakukan karena ketiadaan anggaran sehingga perbaikan pasar hanya sebatas renovasi bangunan fisik saja kurang diikuti memperbaiki manajemen pasar, perawatan, dan lainlain.

Salah satu pasar baru atau pasar tradisional yang saat ini sudah mulai beroperasional dengan baik adalah Pasar Tradisional Sukawinatan yang terletak di Suka Bangun II Km.6 Palembang. Pasar Tradisional ini ini memiliki dua tingkat dengan daya tampung lebih kurang 200 pedagang, dengan 50 kios/lapak dengan ukuran standar pasar tradisonal yakni $2 \times 3 \mathrm{~m}^{2}$. Tingkat pertama untuk pedagang sembako sedangkan tingkat kedua diperuntukkan untuk pedagang pakaian dan perabot atau kebutuhan rumah tangga lainnya. Para pedagang Pasar Tradisional Sukawinatan adalah pedagang yang berasal dari sekitar wilayah sukawinatan dan pedagang datangan yang memang menyewa/membeli tempat atau kios. Para pedagang tersebut beberapa adalah UMKM (Usaha Mikro, Kecil, dan Menengah). Adanya pasar Tradisional Sukawinatan ini telah memberikan kesempatan bagi para pedagang khususnya UMKM untuk memiliki tempat atau kios dengan harga murah dan lokasi pasar yang strategis. Beberapa pedagang UMKM yang ada di Pasar Tradisional Sukawinatan antara lain: pedagang kerajinan sarung bantal guling dan kasur lihab, pedagang kerupuk dan kemplang, penjahit baju, pedagang kerajinan anyaman, pedagang aneka makanan dan kue kering, dan lain sebagainya.

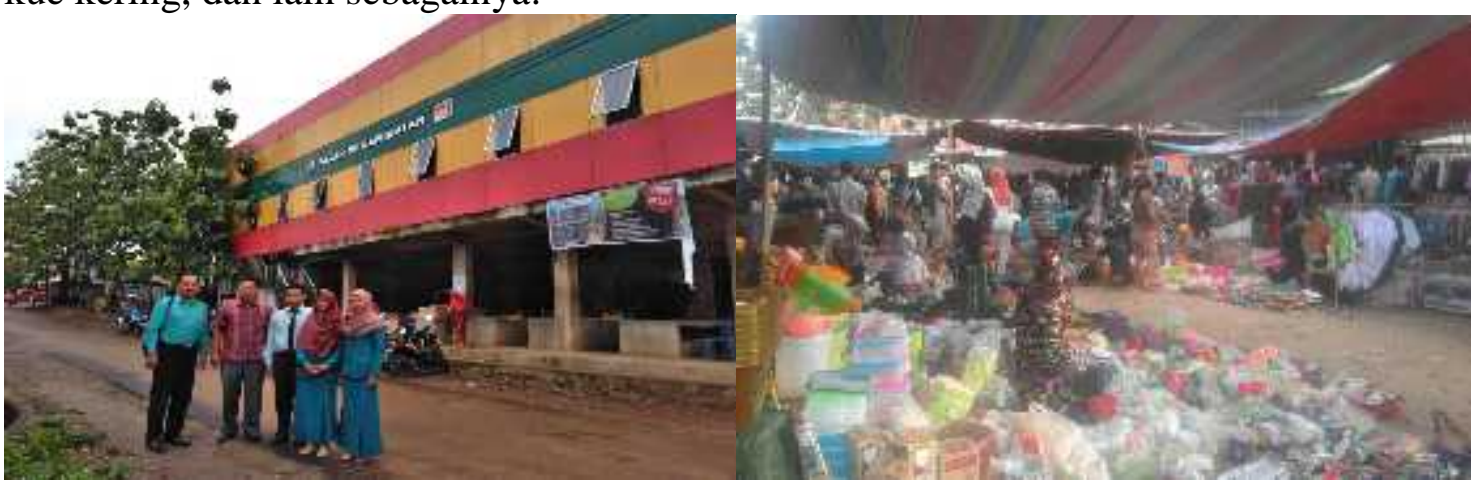




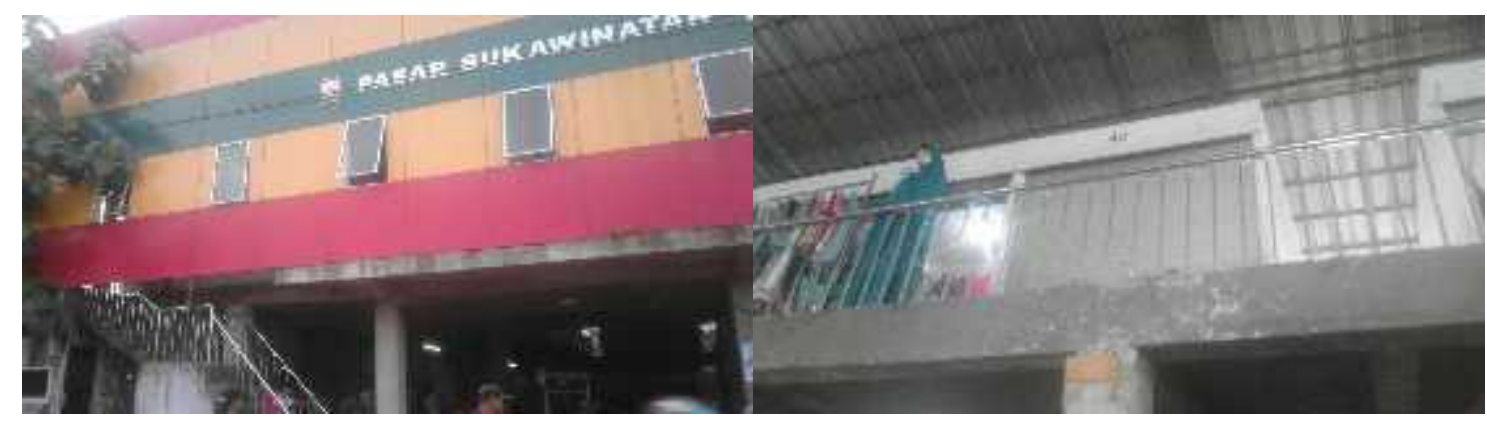

Gambar 1. Kondisi Pasar Tradisonal Sukawinatan

Beberapa masalah yang dihadapi pengusaha mikro adalah satunya adalah permodalan. Masalah permodalan adalah merupakan salah satu masalah utama yang dihadapi pengusaha mikro. Umumnya pengusaha mikro terbentur pada masalah modal yang akan digunakan dalam mengembangkan usaha, meskipun banyak pengusaha yang mempunyai kemampuan untuk mengolah usahanya tetapi tidak mempunyai modal yang cukup sehingga pengusaha ini dapat mengembangkan usahanya lebih maju. Jelaslah modal merupakan faktor yang utama untuk menentukan arah perkembangan usaha yang dijalankan. Seperti diketahui modal sangat penting dalam perkembangan usaha karena modal mempunyai dua fungsi, yaitu:

1. Menopang kegiatan produksi dan penjualan dengan jalan menjembatani antara saat pengeluaran untuk pembelian bahan serta jasa yang diperlukan dengan penjualan.

2. Menutup pengeluaran yang bersifat tetap dan pengeluaran yang tidak ada hubungannya secara langsung dengan produksi dan penjualan. Jadi jelaslah modal sangat diperlukan dalam pengembangan perusahaan, dan tanpa modal perusahaan/usaha yang dijalankan tidak dapat beroperasi dengan baik.

Oleh karena itu, perlu peran dari banyak pihak untuk membantu bangkitnya dan berkembangnya usaha mikro. Salah satunya dengan memberikan pengetahuan dan peningkatan kemampuan dalam membuat proposal pengajuan kredit bank dalam rangka mendapatkan permodalan dari bank untuk mengembangkan usahanya. Saat ini, banyak tawaran kredit mikro dari pihak perbankan yang sedang digalakkan dan dipermudah persyaratannya untuk membantu pengembangan UMKM, akan tetapi tetap harus mengajukan proposal pengajuan kredit mikro. Para pedagang Pasar Tradisional Sukawinatan adalah UMKM yang kebanyakan mengalami kesulitan informasi dalam pengajuan kredit mikro ke bank bagi pengembangan usahanya. Banyak pedagang atau pelaku UMKM tersebut yang mengeluhkan mengenai ketidaktahuan atau ketidakpahaman mereka tentang proposal pengajuan kredit mikro ke bank. Hal ini dikarenakan latar belakang pendidikan dan kurangnya informasi yang mereka terima. Hasil wawancara yang dilakukan dengan 25 para pedagang UMKM di Pasar Tradisional Sukawinatan didapatkan data bahwa 18 orang tamatan SMP dan 7 orang tamatan SMA. Mereka semua menjawab belum pernah membuat proposal pengajuan kredit bank padahal mereka ingin mengembangkan usahanya karena usaha mereka ratarata telah berdiri sekitar 4-6 tahun. Berdasarkan latar belakang tersebut, maka penting untuk dilaksanakan kegiatan pengabdian masyarakat dalam bentuk pelatihan dan pendampingan pembuatan proposal pengajuan kredit bank bagi para pedagang Pasar Tradisional Sukawinatan.

Oleh karena, para pedagang Pasar Tradisional Sukawinatan beberapa diantaranya adalah pelaku atau pemilik dari UMKM (Usaha Mikro, Kecil, dan Menengah), yang berkeinginan untuk mengembangkan usaha mereka melalui pembiayaan kredit dari 
Bank. Akan tetapi, para pedagang tersebut tidak memiliki pengetahuan mengenai bagaimana membuat proposal kredit bank. Seperti yang diketahui, bahwa satu di antara faktor yang menyebabkan usaha UMKM tidak mengalami kemajuan berarti atau bahkan sampai bangkrut dikarenakan ketidaktahuan para pelaku atau pemilik UKM tentang bagaimana membuat proposal pinjaman modal dan pengembangan usaha. Para pedagang yang sekaligus pelaku atau pemilik dari UMKM di Pasar Tradisional Sukawinatan diharapkan akan mengerti kalau usahanya dapat berkembang karena dalam pelatihan dan pendampingan ini diajarkan mengenai pengembangan usaha dan manajemen permodalan serta bagaimana membuat proposal pengajuan kredit bank yang selama ini tidak mereka ketahui.

Berdasarkan identifikasi dan perumusan masalah tersebut serta hasil Focus Group Discussion (FGD) dengan mitra, maka tujuan kegiatan pengabdian ini adalah memberikan pelatihan dan pendampingan pembuatan proposal pengajuan kredit bank kepada para pedagang UMKM di Pasar Tradisional Sukawinatan. Kondisi baru yang diharapkan terwujud setelah kegiatan pengabdian masyarakat ini adalah pedagang UMKM mampu membuat proposal pengajuan kredit kepada pihak bank secara benar dan baik. Manfaat kegiatan pengabdian masyarakat ini adalah memberikan kemampuan kepada para pedagang UMKM untuk membuat proposal pengajuan kredit bank secara benar dan baik. Dengan kemampuan tersebut mereka dapat mengajukan kredit bank dalam rangka pengembangan usahanya tentu saja dengan tetap memperhatikan prinsip 5C dan 7P. Disamping itu, menerapkan manajemen permodalan yang baik untuk usaha mereka. Jumlah peserta aktif yang mengikuti kegiatan pengabdian ini sebanyak 16 orang pedagang UMKM di Pasar Tradisional Sukawinatan.

\section{B. TINJAUAN PUSTAKA Proposal}

Pengajuan tertulis berisikan informasi perusahaan yang diberikan kepada bank. Pengajuan tertulis ini disebut dengan proposal kredit. Secara umum isi suatu proposal kredit dapat diringkas sebagai berikut: ringkasan eksekutif, identitas, gambaran umum, gambaran umum, kondisi keuangan, analisis industri, struktur keuangan (proposal kredit), analisis proyeksi keuangan, jaminan kredit, lampiran (Jusuf, 2003).

\section{Pengertian Kredit}

Ikatan Akuntan Indonesia (2004:31.4) mendefinisikan kredit sebagai berikut: Kredit adalah pinjaman uang atau tagihan yang dapat dipersamakan dengan itu berdasarkan persetujuan atau kesepakatan pinjammeminjam antara bank dan pihak lain yang mewajibkan pihak peminjam untuk melunasi utangnya setelah jangka waktu tertentu dengan jumlah bunga, imbalan, atau pembagian hasil keuntungan. Hal yang termasuk dalam pengertian kredit yang diberikan adalah kredit dalam rangka pembiayaan bersama, kredit dalam restrukturisasi, dan pembelian surat berharga nasabah yang dilengkapi dengan Note Purchase Agreement (NPA). Dari pengertian di atas dapatlah dijelaskan bahwa kredit dapat berupa uang atau tagihan yang nilainya diukur dengan uang. Kemudian adanya kesepakatan antara bank sebagai kreditur dan nasabah penerima kredit sebagai debitur, dengan perjanjian yang telah dibuat. Dalam perjanjian kredit tercakup hak dan kewajiban masing-masing pihak, termasuk jangka waktu

Istilah kredit banyak dipakai dalam sistem perbankan konvensional yang berbasis pasar bunga (interest based), sedangkan dalam hukum perbankan syariah lebih dikenal dengan istilah pembiayaan (financing) yang berbasis pada keuntungan riil yang 
dikehendaki (margin) ataupun bagi hasil (profit sharing). Pengertian kredit disebutkan dalam Pasal 1 angka 11 Undang-Undang Nomor 10 Tahun 1998, yang berbunyi: "Kredit adalah penyediaan uang atau tagihan yang dapat dipersamakan dengan itu, berddasarkan persetujuan atau kesepakatan pinjam-meminjam antara bank dengan pihak lain yang mewajibkan pihak peminjam untuk melunasi utangnya setelah jangka waktu tertentu dengan pemberian bunga."

Dalam perbankan konvensional penyaluran dana kepada nasabah selalu dalam bentuk uang yang kemudian terserah bagi nasabah debitur untuk memakainya. Sedangkan dalam perbankan syariah biasanya bank menyediakan pembiayaan dalam bentuk penyediaan barang nyata (asset) baik yang didasarkan pada konsep jual-beli, sewa-menyewa, ataupun bagi hasil (Kasmir, 2002).

Unsur-unsur yang terkandung dalam pemberian suatu fasilitas kredit adalah sebagai berikut (Firdaus dan Ariyanti, 2009).

1. Adanya badan atau orang yang memiliki uang, barang atau jasa yang bersedia untuk meminjamkan kepada fihak lain. orang atau barang demikian lazim disebut kreditur,

2. Adanya fihak yang membutuhkan/meminjam uang, barang atau jasa. Fihak ini lazim disebut debitur,

3. Adanya kepercayaan dari kreditur terhadap debitur,

4. Adanya janji dan kesanggupan membayar dari debitur kepada kreditur,

5. Adanya perbedaan waktu yaitu perbedaan antara saat penyerahan uang, barang atau jasa oleh kreditur dengan pada saat pembayaran kembali dari debitur,

6. Adanya resiko yaitu sebagai akibat dari adanya perbedaan waktu seperti di atas, dimana masa yang akan datang merupakan suatu yang belum pasti, maka kredit itu pada dasarnya mengandung resiko, termasuk penurunan nilai uang karena inflasi dan sebagainya,

7. Adanya bunga yang harus dibayar oleh debitur kepada kreditur (walaupun ada kredit yang tidak berbunga).

\section{Prinsip-prinsip Pemberian Kredit}

Prinsip-prinsip pemeberian kredit menggunakan analisis 5C dan 7P. Adapun penjelasan analisis 5C kredit adalah sebagai berikut: 1). Character, suatu keyakinan bahwa sifat atau watak dari orang-orang yang akan diberikan kredit benar-benar dapat dipercaya, hal ini tercermin dari latar belakang nasabah baik yang bersifat pribadi seperti cara hidup atau gaya hidup yang dianutnya, keadaan keluarga, hobi dan social standing-nya. Ini semua merupakan ukuran kemauan untuk membayar, 2). Capacity, untuk melihat nasabah dalam kemampuannya dalam bidang bisnis yang dihubungkan dengan pendidikannya, kemampuan bisnis juga diukur dengan kemampuannya dalam memahami tentang ketentuan-ketentuan pemerintah. Begitu pula, dengan kemampuannya dalam menjalankan usahanya, termasuk kekuatan yang ia miliki. Pada akhirnya akan terlihat kemampuannya dalam mengembalikan kredit yang disalurkan, 3). Capital, untuk melihat penggunaan modal apakah efektif, dilihat dari laporan keuangan (neraca dan laporan rugi laba) dengan melakukan pengukuran seperti dari segi likuiditas dan solvabilitasnya, rentabilitas dan ukuran lainnya. Capital juga harus dilihat dari sumber modal yang sekarang ini, 4). Colateral, merupakan jaminan yang diberikan calon nasabah baik yang bersifat fisik maupun non-fisik. Jaminan hendaknya melebihi jumlah kredit yang diberikan. Jaminan juga harus diteliti keabsahannya, sehingga jika terjadi suatu masalah, maka jaminan yang dititipkannya akan dapat dipergunakan secara mungkin, dan 5). Condition of Economic, dalam menilai kredit hendaknya juga dinilai kondisi ekonomi sekarang dan kemungkinan untuk dimasa yang akan datang sesuai 
sektor masing-masing serta diakibatkan dengan prospek usaha dari sektor yang dijalankan. Penilaian prospek bidang usaha yang dibiayai hendaknya benar-benar memiliki prospek yang baik, sehingga kemungkinan kredit bermasalah tersebut relatif kecil.

Keadaan ekonomi pada umumnya yang mungkin dapat mempengaruhi usaha calon nasabah dan lain-lain, dengan memperhatikan dan mengetahui hal-hal tersebut diharapkan bantuan kredit yang diberikan benar-benar dapat bermanfaat bagi usahanya. Sedangkan penilaian dengan analisis 7P kredit adalah sebagai berikut: 1. Personality, yaitu menilai nasabah dari segi kepribadiannya atau tingkah lakunya sehari-hari maupun masa lalunya, 2. Party, yaitu mengklarifikasikan nasabah ke dalam klasifikasi tertentu atau golongan-golongan tertentu berdasarkan modal, loyalitas serta karakternya sehingga nasabah dapat digolongkan ke golongan tertentu dan akan mendapatkan fasilitas yang berbeda dari bank, 3). Purpose, yaitu untuk mengetahui tujuan nasabah dalam mengambil kredit, termasuk jenis kredit yang diinginkan nasabah. Tujuan pengambilan kredit dapat bermacam-macam, contoh apakah untuk modal kerja atau investasi, konsumtif atau produktif dan lain sebagainya, 4). Prospect, yaitu untuk menilai usaha nasabah di masa yang akan datang apakah menguntungkan ataukah tidak. Atau dengan kata lain mempunyai prospek ataukah sebaliknya. Hal ini penting mengingat jika suatu fasilitas kredit yang dibiayai tanpa mempunyai prospek, bukan hanya bank yang rugi akan tetapi juga nasabah, 5). Payment, merupakan ukuran bagaimana cara nasabah mengembalikan kredit yang telah diambil atau dari sumber mana saja dana untuk pengembalian kredit. Semakin banyak sumber pengembalian debitur, makan akan semakin baik sehingga jika salah satu usahanya merugi akan dapat ditutupi oleh sektor lainnya, 6). Profitability, untuk menganalisis bagaimana kemampuan nasabah dalam mencari laba. Profitability diukur dari periode ke periode apakah akan tetap sama atau akan semakin meningkat, apalagi dengan tambahan kredit yang akan diperolehnya, dan 7). Protection, tujuannya adalah bagaimana menjaga agar usaha dan jaminan mendapatkan perlindungan. Perlindungan dapat berupa jaminan barang datau orang atau jaminan asuransi.

\section{Jenis-jenis Kredit}

Jenis-jenis kredit dibedakan berdasarkan sudut pendekatan yang dilakukan berdasarkan tujuan kegunaannya, jangka waktu, macam, sektor perekonomian, agunan, golongan ekonomi, serta penarikan dan pelunasan (Hasibuan, 2009). Menurut Hasibuan (2009), berdasarkan tujuan/kegunaannya kredit anatara lain: 1). Kredit konsumtif yaitu kredit yang dipergunakan untuk kebutuhan sendiri bersama keluarganya, 2). Kredit modal kerja (kredit perdagangan) ialah kredit yang akan dipergunakan untuk menambah modal usaha debitur, 3). Kredit investasi ialah kredit yang dipergunakan untuk investasi produktif, tetapi baru akan menghasilkan dalam jangka waktu yang relatif lama.

Berdasarkan jangka waktu, kredit antara lain: 1). Kredit jangka pendek yaitu kredit yang jangka waktunya paling lama satu tahun saja, 2). Kredit jangka menengah yaitu kredit yang jangka waktunya antara satu sampai tiga tahun, 3). Kredit jangka panjang yaitu kredit yang jangka waktunya lebih dari tiga tahun (Hasibuan, 2009). Berdasarkan macamnya, kredit dibedakan menjadi: 1). Kredit aksep yaitu kredit yang pada hakikatnya hanya merupakan pinjaman uang biasa sebanyak plafond kredit (L3/BMPK)-nya, 2). Kredit penjual yaitu kredit yang diberikan penjual kepada pembeli, artinya barang yang telah diterima pembayaran kemudian, 3). Kredit pembeli adalah pembayaran telah dilakukan kepada penjual, tetapi barangnya diterima belakangan atau pembelian dengan uang muka (Hasibuan, 2009). 
Berdasarkan agunan/jaminan, kredit dibagi menjadi: 1). Kredit agunan orang ialah kredit yang diberikan dengan jaminan seseorang terhadap debitur bersangkutan, 2). Kredit agunan efek ialah kredit yang diberikan dengan agunan efek-efek dan surat-surat berharga, 3). Kredit agunan barang ialah kredit yang berikandengan agunan barang tetap, barang bergerak dan logam mulia, 4). Kredit agunan dokumen ialah kredit yang diberikan dengan agunan dokumen transaksi (Hasibuan, 2009). Berdasarkan golongan ekonomi, kredit dibagi menjadi:. 1) Golongan ekonomi lemah ialah kredit yang disalurkan kepada pengusaha golongan ekonomi lemah. Golongan ekonomi lemah adalah pengusaha yang kekayaan maksimumnya sebesar Rp 600 juta, tidak termasuk tanah dan bangunannya. 2) Golongan ekonomi menengah dan konglomerat adalah kredit yang diberikan kepada pengusaha menengah dan besar (Hasibuan, 2009). Jenisjenis kredit antara lain: (dikutip dalam Tristiarto dkk, 2017)

1. Kredit Konsumtif, yaitu kredit yang digunakan oleh nasabah untuk memenuhi kebutuhan pribadinya.

2. Kredit produktif, yaitu kredit yang digunakan oleh nasabah untuk meningkatkan aktivitas perudahaan (menghasilkan sesuatu). Kredit ini dibagi dua, yaitu :1) Kredit Investasi yaitu kredit yang digunakan untuk membeli barang-barang modal. 2) Kredit Modal Kerja yaitu kredit yang digunakan untuk membeli bahan baku.

\section{Fungsi Kredit}

Menurut Firdaus (2003), fungsi pokok kredit pada dasarnya ialah pemenuhan jasa untuk melayani kebutuhan masyarakat dalam rangka mendorong dan melancarkan produksi, jasa-jasa dan bahkan konsumen yang semuanya itu ditujukan untuk meningkatkan taraf hidup manusia. Fungsi dari suatu kredit bagi masyarakat yaitu: a. Menjadi motivator peningkatan kegiatan perdagangan dan perekonomian. $b$. Memperluas lapangan kerja bagi masyarakat. c. Memperlancar arus barang dan arus uang. d. Meningkatkan produktivitas yang ada. e. Meningkatkan kegairahan berusaha mesyarakat. f. Memperbesar modal kerja perusahaan (Kasmir, 2002).

\section{Tujuan Kredit}

Suyatno (2004) menyatakan bahwa pemberian kredit dimaksudkan untuk memperoleh keuntungan, oleh karena itu Bank memberikan pinjaman kepada nasabahnya dalam bentuk kredit, jika merasa yakin nasabah yang akan menerima kredit itu mampu dalam memberikan kredit yang telah diterimanya. Dalam kaitannya dengan pemberian kredit, kredit memiliki tujuan pokok yang saling berhubungan: a. Profitabilitas yaitu tujuan untuk memperoleh hasil dari kredit berupa keuntungan yang dapat dari bunga pinjaman. b. Safety yaitu keamanan dari prestasi atau fasilatas yang diberikan harus benarbenar terjamin sehingga tujuan profitabilitas dapat tercapai.

Kasmir (2001) tujuan pemberian kredit adalah:

1. Mencari Keuntungan, yaitu bertujuan untuk memperoleh hasil dari pemberian kredit tersebut, hasil tersebut terutama dalam bentuk bunga yang diterima oleh Bank sebagai balas jasa dan biaya admistrasi kredit yang diberikan kepada nasabah.

2. Membantu Usaha Nasabah Tujuan lainnya adalah untuk membantu usaha nasabah yang memerlukan dana, baik dana investasi maupun dana untuk modal kerja.

3. Membantu Pemerintah Bagi Pemerintah semakin banyak kredit yang disalurkan oleh pihak perbankan maka makin baik, berarti adanya peningkatan pembangunan di berbagai sektor.

\section{Manfaat Kredit}

Manfaat kredit bank apabila dilihat dari berbagai pihak yang berkepentingan (stakeholder) sebagai berikut; 
1. Manfaat kredit bank bagi debitur

- Untuk meningkatkan usahanya maka debitur dapat menggunakan dana kredit untuk pengadaan atau peningkaan berbagai faktor produksi, baik berupa tambahan modal kerja, mesin, bahan baku, maupun peningkatan sumber daya manusia, metode, pasar, sumber daya alam dan teknologi.

- Kredit bank relatif mudah diperoleh apabila usaha debitur layak untuk dibiayai.

- Biaya yang dikeluarkan untuk memperoleh kredit bank (antara lain provisi dan bunga) relatif murah.

- Terdapat berbagai macam/jenis/tipe kredit yang disediakan oleh perbankan, sehingga calon debitur dapat memilih jenis yang paling sesuai.

- Dengan memperoleh kredit dari bank, biasanya debitur tersebut sekaligus terbuka kesempatannya untuk menikmati produk/jasa bank lainnya seperti transfer, bank garansi, pembukaan letter of credit dan lain sebagainya.

- Rahasia keuangan debitur terlindungi.

- Jangka waktu kredit dapat disesuaikan dengan kebutuhan calon debitur.

2. Manfaat kredit bagi bank

Bank memperoleh pendapatan berupa bunga yang diterima dari debitur. Disamping bunga, walaupun jumlahnya tidak signifikan diperoleh pula pendapatan dari provisi/biaya administrasi dan denda (penalty) dan Fee Base Income (biaya transfer, L/C iuran credit card/ATM) dan sebagainya. Dengan diperolehnya pendapatan bunga kredit, maka diharapkan rentabilitas bank akan membaik yang tercermin dalam perolehan laba yang meningkat. Dengan pemberian kreditnya, bank sekaligus dapat memasarkan produkproduk/jasa-jasa bank lainnya seperti giro, tabungan, deposito, sertifikat deposito, transfer, jaminan bank, dan lain sebagainya. Produk atau jasa-jasa tersebut dijual melalui salah satu persyaratan yang tertuang dalam perjanjian kredit dimana debitur harus menyalurkan semua kegiatan usahanya melalui bank yang bersangkutan. Dengan adanya kegiatan pemberian kredit, maka bank dapat mendidik dan meningkatkan kemampuan para personilnya untuk lebih mengenal secara rinci kegiatan usaha secara riil di berbagai sektor ekonomi. Personil/tenaga kerja yang terdidik dan terlatih sehingga mempunyai keahlian khusus merupakan asset yang sangat berharga bagi bank.

3. Manfaat kredit bagi Pemerintah atau Negara Kredit bank dapat dipergunakan sebagai alat untuk mendorong pertumbuhan ekonomi baik secara umum maupun untuk sektor tertentu saja. Kredit bank dapat dijadikan alat/ pengendalian moneter. manakala uang yang besar dianggap terlalu banyak sehingga berdampak inflatoir (dimana harga barang dan jasa pada umumnya meningkat), maka kredit bank harus dikurangi antara lain melalui kenaikan suku bunga atau pembatasan jumlah kredit, sehingga masyarakat enggan untuk meminjam atau kesempatan meminjam menjadi berkurang. Begitu pula sebaliknya dengan cara seperti itu arus tukar menukar barang dan jasa menjadi lancar. Kredit bank dapat menciptakan dan menigkatkan lapangan usaha dan lapangan kerja. Kredit bank dapat menciptakan dan meningkatkan pemerataan pendapatan masyarakat. Secara tidak langsung pemberian kredit bank akan meningkatkan pendapatan Negara yang berasal dari pajak perusahaan yang tumbuh dan berkembang volume usahanya. Pemberian kredit bank yang sahamnya dimiliki oleh pemerintah/Negara/daerah yang berhasil meningkatkan labanya, akan menambah pendapatan pemerintahan/negara/daerah yang berupa setoran bagian deviden yang bersangkutan. Pemberian kredit bank dapat menciptakan dan memperluas pasar. Dengan adanya kredit bank maka volume produksi dan konsumsi 
akan meningkatdan hal itu akan mendorong terciptanya pasar baru serta peningkatan pasar yang telah ada.

4. Manfaat kredit bagi masyarakat Kredit bank yang mendorong pertumbuhan dan perluasan ekonomi, maka akan mengurangi tingkat pengangguran dan meningkatkan tingkat pendapatan masyarakat. Untuk kelompok masyarakat yang memiliki keahlian dan profesi tertentu dapat terlibat dalam proses pemberian kredit, misalnya seorang konsultan proyek dapat turut serta dalam pembuatan project proposal atau studi kelayakan proyek (project feasibility study). Bagi notaris dapat terlibat dalam pembuatan perjanjian kredit dan pengikatan jaminan dan lain sebagainya. Para pemilik dana yang menyimpan di bank berharap agar kredit bank berjalan lancar, sehingga dana mereka yang digunakan/disalurkan oleh bank dapat diterima kembali secara utuh beserta sejumlah bunganya sesuai kesepakatan.

\section{Pengertian kredit Usaha Mikro Kecil dan Menengah}

Menurut Undang-Undang No. 20 tahun 2008 tentang UMKM adalah Usaha produktif milik orang perorang dan atau badan usaha perorangan yang memenuhi kriteria usaha mikro, memiliki kekayaan bersih paling banyak Rp 50.000.000 (lima puluh juta rupiah) tidak termasuk tanah dan bangunan tempat usaha atau memiliki hasil penjualan tahunan paling banyak Rp. 300.000.000,00 (tiga ratus juta rupiah).

\section{Prosedur Pemberian Kredit}

Secara umum proses pemberian kredit oleh badan hukum adalah sebagai berikut: (Hasibuan, 2008)

1. Pengajuan proposal. Yang perlu diperhatikan dalam mengajukan proposal kredit adalah suatu yang berisi keterangan tentang : Riwayat perusahaan, seperti riwayat hidup perusahaan, jenis bidang usaha, nama pengurus, berikut latar belakang pendidikanya, perkes pengambangan perusahaan serta wilayah pemasaran produknya. Tujuan pengambilan kredit, dalam hal ini harus jelas tujuan pengambilan kreditnya. Apakah untuk memperbesar omzet penjualan atau memperbesar kapasitas produksi atau untuk mendirikan pabrik baru (perluasan) serta tujuan lainnya. Besarnya kredit dan jangka waktu, dalam hal ini bank harus mengetahui besarnya kredit dan jangka waktu pengembalian kredit. Cara pemohon mengembalikan kredit maksudnya perlu dijelaskan secara rinci cara-cara nasabah mengembalikan kreditnya apakah dari hasil penjulan atau cara lainnya. Jaminan kredit, jaminan yang dimaksud dalam bentuk sertifikat atau sertifikat dan harus diteliti keabsahannya, biasanya suatu jaminan diikat dengan suatu asuransi tertentu. Selanjutnya proposal ini dilengkapi dengan berkas - berkas yang telah dipersyaratkan sebagai berikut : Akte pendirian perusahaan, Bukti diri (KTP) para pengurus dan pemohon, T.D.P (Tanda Daftar Perusahaan), N.P.W.P (Nomor Pokok wajib Pajak), Neraca dan laporan labarugi 3 tahun terakhir, Fotocopy sertifikat yang dijadikan jaminan, Daftar penghasilan bagi perseorangan, Kartu Keluarga ( KK ) bagi perorangan.

2. Penyelidikan berkas pinjaman. Dalam penyelidikan hal hal yang perlu diperhatikan adalah membuktikan kebenaran dan keaslian dari berkas-berkas yang ada, seperti keaslian dan kebenaran dari akte notaries, TDP, KTP dan suart-surat jaminan, seperti : sertifikat tanah, BPKP mobil ke instansi yang berwenang mengeluarkannya. Kemudian jika benar dan asli maka bank akan mengkalkulasi apakah jumlah kredit yang diminta apakah relevan dan kemampuan nasabah untuk membayar. Semua ini digunakan terhadap angka dalam laporan keuangan dengan berbagai rasio keuangan yang ada. 
3. Penilaian kelayakan kredit. Adapun aspek-aspek yang perlu dinilai dalam pemberian fasilitas kredit adalah : Aspek hukum, Aspek pasar dan pemasaran, Aspek keuangan, Aspek operasi/teknis, Aspek manajemen, Aspek ekonomi sosial, Aspek AMDAL,

4. Wawancara pertama

5. Peninjauan lokasi (on the spot)

6. Wawancara kedua

7. keputusan kredit

8. penandatangan akad kredit/perjanjian lainnya

9. Realisasi kredit

\section{METODE PELAKSANAAN KEGIATAN}

Obyek atau sasaran strategis dalam penyuluhan ini adalah para pedagang Pasar Tradisional Sukawinatan yang juga sekaligus pelaku atau pemilik UMKM dengan jumlah peserta aktif sebanyak 16 orang. Rangkaian kegiatan pelatihan ini dilaksanakan pada bulan September 2016 - Pebruari tahun 2017. Metode pelaksanaan kegiatan pengabdian kepada masyarakat ini adalah melalui:

1. Kegiatan penyuluhan pentingnya materi pengembangan usaha dan materi manajemen permodalan bagi usaha mikro yang dilanjutkan dengan sesi tanya jawab peserta penyuluhan.

2. Kegiatan pelatihan dan pendampingan, dengan cara penyajian materi, praktik simulasi pembuatan proposal pengajuan kredit bank.

Penyampaian materi dilakukan dengan mengedepankan teknik dengan pendekatan pemotivasian dan disesuaikan dengan tingkat pengetahuan peserta, agar materi yang disampaikan dapat dengan mudah dicerna oleh para peserta. Pelatihan ini diberikan untuk membantu para pedagang yang juga yang juga sekaligus pelaku atau pemilik UMKM untuk dapat mengembangkan usahanya dengan memperoleh pembiayaan kredit dari bank. Adapun proses dan tahapan pelaksanaan program adalah sebagai berikut:

1. Tahap awal, tim pelaksana mengadakan persiapan dengan melakukan survei untuk mendapatkan identifikasi masalah mitra melalui wawancara dengan 25 orang pedagang UMKM di Pasar Tradisional Sukawinatan. Selain itu juga melakukan wawancara dengan pihak pengelola Pasar Tradisional Sukawinatan untuk mendapatkan gambaran mengenai obyek program atau analisis situasinya. Berdasarkan hasil identifikasi masalah yang dihadapi oleh mitra maka didapatlah solusi. Tim pelaksana juga melakukan FGD dengan beberapa pedagang UMKM di Pasar Tradisional Sukawinatan untuk kesediaan mengikuti program pengabdian masyarakat sehingga didapatkanlah 16 peserta aktif yang bersedia mengikuti program. Adapun sarana prasarana pendukung untuk pelaksanaan program adalah kemudahan akses untuk melaksanakan FGD, kemudahan menemui para pedagang, dan fasilitasi rumah warga yang berada di sekitar Pasar Tradisional Sukawinatan bernama Ibu Kartini, yang menyediakan tepat untuk pelaksanaan program. Tim pelaksana juga menyiapkan beberapa handout untuk peserta sehubungan dengan materi pengembangan usaha dan materi manajemen permodalan bagi usaha mikro serta contoh proposal pengajuan kredit bank.

2. Tahap pelaksanaan, pada tahap ini dilaksanakan kegiatan penyuluhan pentingnya materi pengembangan usaha dan materi manajemen permodalan bagi usaha mikro yang dilanjutkan dengan sesi tanya jawab peserta penyuluhan. Selanjutnya diadakan kegiatan pelatihan dan pendampingan, dengan cara penyajian materi dan praktik pembuatan proposal pengajuan kredit bank serta proses pendampingan selama 3 hari. 
Keaktifan/antusiasme para peserta ditunjukkan melalui pertanyaan yang diajukan setelah sesi penyampian materi oleh narasumber. Disamping itu selesainya 4 proposal pada saat proses pendampingan, yang dibuat oleh pedagang yang memang mau mengajukan kredit bank untuk pengembangan usaha dalam waktu dekat.

3. Tahapan Monitoring dan Evaluasi. Monitoring dan evaluasi kegiatan pengabdian masyarakat ini dilakukan melalui kuesioner dan banyaknya proposal yang mampu dihasilkan dari kegiatan pendampingan. Untuk keperluan evaluasi hasil kuesioner tingkat pemahaman para peserta dalam memahami materi yang sudah disampaikan dikelompokkan menjadi: $91 \%$ - 100\%= amat baik, $81 \%-90,00 \%=$ baik, $71 \%$ $80,99 \%=$ cukup, $61 \%-70,99 \%=$ kurang.

\section{HASIL KEGIATAN}

Pemecahan masalah dilakukan dengan metode penyuluhan dan penyajian materi serta tanya jawab, kegiatan praktik dan pendampingan pembuatan proposal pengajuan kredit bank secara langsung. Para peserta awalnya diberikan penyuluhan tentang pentingnya mengembangkan usaha dan manajemen permodalan dengan menjelaskan prosedur sederhana yang harus dilakukan untuk mendapatkan kredit bank dan sekaligus meningkatkan kemampuan pelaksanaan prinsip ekonomi yang sehat. Penyuluhan mengenai pengembangan usaha berisi cara-cara mengembangkan usaha kecil. Adapun beberapa hal yang difokuskan dalam materi pengembangan usaha, adalah: bagaimana membuat perencanaan sebuah strategi, melakukan penghematan biaya operasional setiap bulan, bagaimana mengenali para pesaing usaha, dan bagaimana melakukan survei harga pasar. Sedangkan penyuluhan mengenai manajemen permodalan bagi usaha mikro berisi tentang apa saja kendala UKM dan bagaimana prosedur pemberian kredit modal kerja oleh pihak perbankan. Beberapa hal yang difokuskan dalam materi manajemen permodalan usaha adalah: kendala apa saja yang dihadapi UKM dan bagaimana prosedur pemberian kredit modal kerja oleh pihak perbankan.

Selanjutnya masuk ke materi pelatihan pembuatan proposal pengajuan kredit bank, bagian demi bagian yang harus ada dalam proposal pengajuan kredit bank. Setelah materi paparan disampaikan, dalam sesi diskusi/tanya jawab banyak peserta yang berpartisipasi secara aktif mengajukan pertanyaan dan bahkan ada yang menyampaikan pengalaman keluarganya seputar kredit bank.

Setelah kegiatan penyuluhan, mulai dari penyuluhan pengembangan usaha dan manajemen permodalan bagi usaha mikro, para peserta diberikan praktik langsung/simulasi pembuatan proposal pengajuan kredit bank. Adapun saat praktik pembuatan proposal pengajuan kredit bank, para peserta diberikan contoh proposal lengkap dengan template-nya. Berikut ini adalah contoh proposal pengembangan usaha yang disampaikan pada kegiatan praktik: 

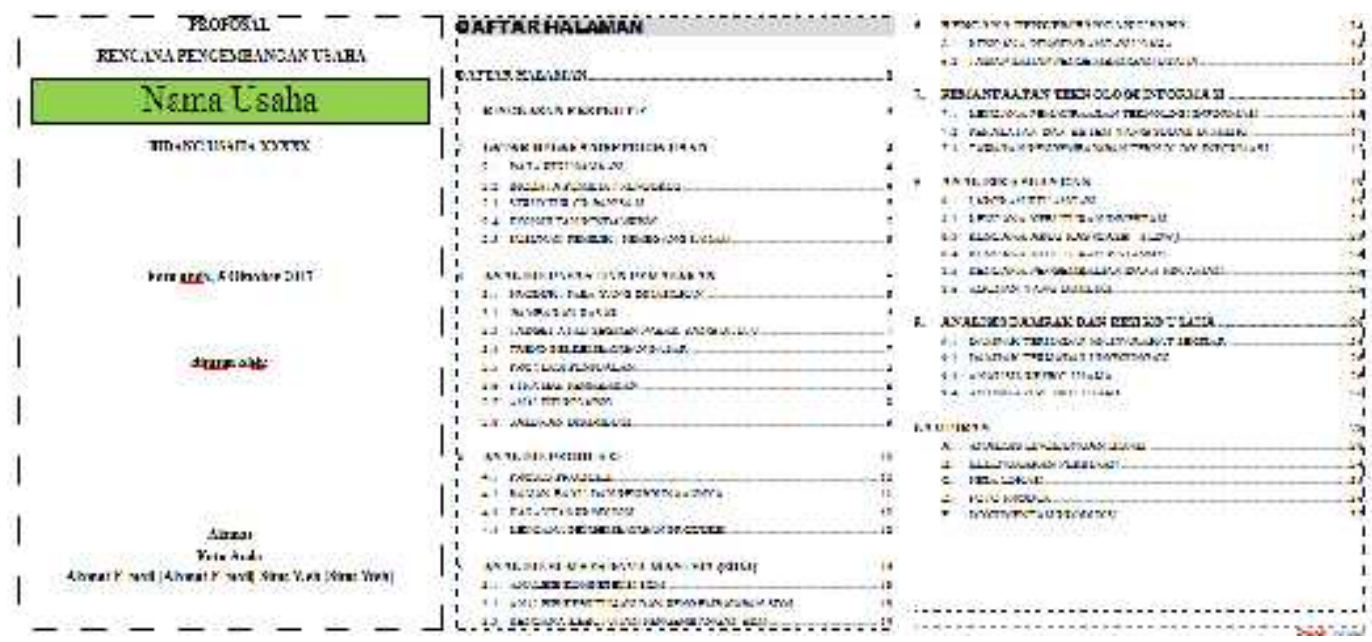

Gambar 2. Proposal Rencana Pengembangan Usaha yang Disertakan Saat Pengajuan

Kredit Bank

Selanjutnya dilakukan kegiatan pendampingan selama 3 hari untuk peserta yang memang akan mengajukan proposal pengajuan kredit bank dalam waktu dekat. Dimana pada proses pendampingan ini tim pelaksana membantu mengoreksi rencana pengembangan usaha yang dibuat oleh peserta. Bagian mana saja dari proposal rencana pengembangan usaha yang perlu ditekankan dan menjadi pusat perhatian pada saat penilaian kelayakan kredit dipenuhi atau tidak oleh pihak manajemen bank.

Hasil kegiatan pelatihan dan pendampingan pembuatan proposal pengajuan kredit bank yang ditujukan pada para pedagang Pasar Tradisional Sukawinatan yang juga sekaligus pelaku atau pemilik UMKM, telah dievaluasi berdasarkan respon dan hasil praktik yang telah dilakukan oleh para peserta dan pendampingan selama 3 hari.

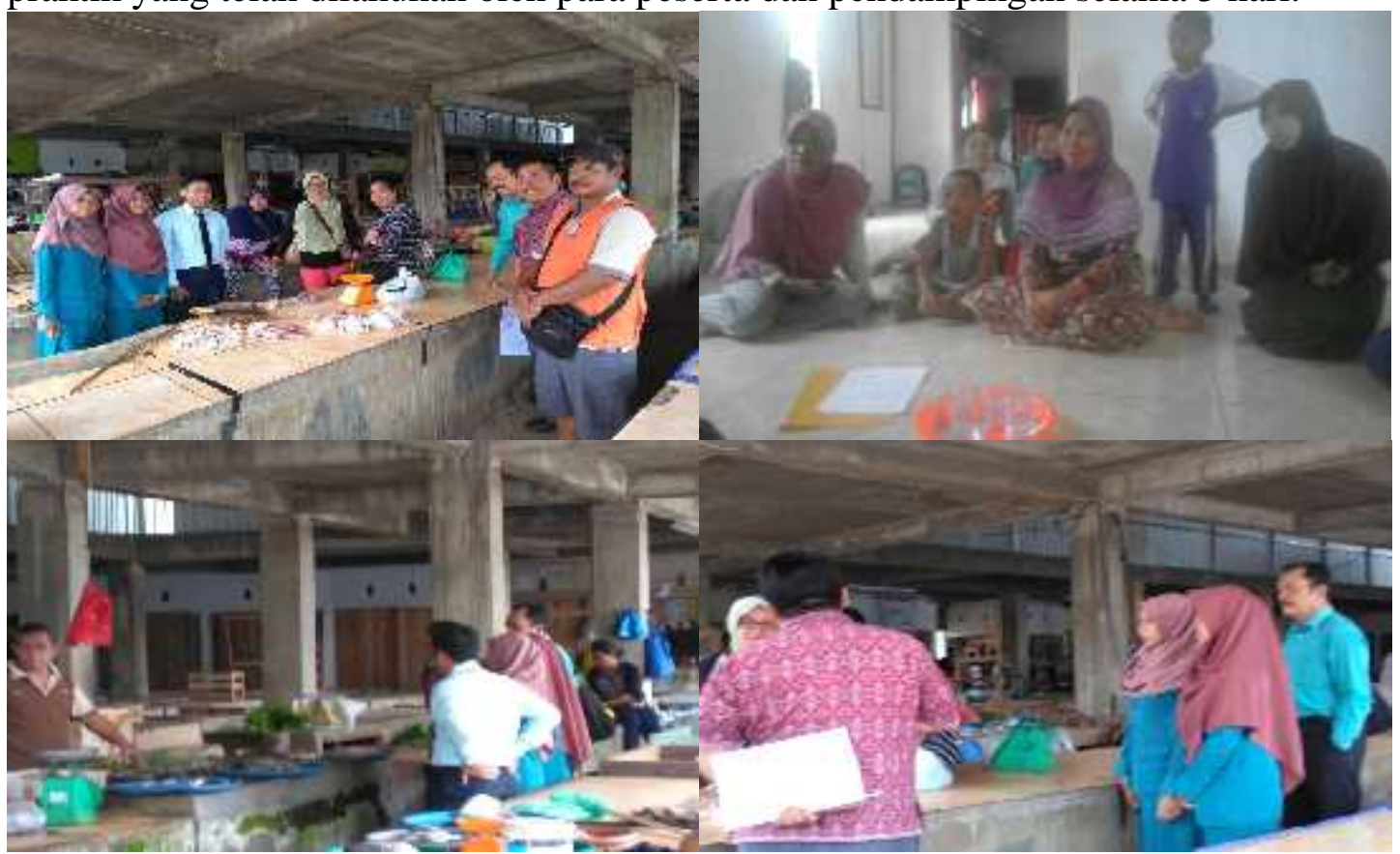

Gambar 3. Kegiatan Pelatihan dan Pendampingan Pembuatan Proposal

Pengajuan Kredit Bank

Evaluasi atas kegiatan pengabdian masyarakat ini dilakukan melalui kuesioner dan hasil umpan balik atas pertanyaan dalam kuesioner sehubungan dengan materimateri pelatihan dan pendampingan pembuatan proposal pengajuan kredit bank serta 
antusiasme para peserta di setiap sesi tanya jawab. Adapun tingkat pemahaman para peserta dalam memahami materi yang sudah disampaikan dikelompokkan pada skala 71\%-80,99\%, maka kegiatan pengabdian masyarakat ini dinyatakan "cukup baik" dan dan tersedia 4 proposal pengajuan kredit bank dari hasil kegiatan pendampingan. Berdasarkan hal tersebut maka efektivitas strategi dan tahapan pelaksanaan program terhadap pencapaian tujuan program pengabdian ini dapat dikatakan baik dan tepat, apalagi telah tersedia 4 proposal dari hasil kegiatan pendampingan. Para peserta telah mengetahui mengenai aspek apa saja yang perlu diperhatikan dalam pengembangan usaha dan manajemen permodalan usaha yang baik serta bagaimana membuat proposal pengajuan kredit bank. Hal tersebut ditunjukkan pula dengan hasil 4 proposal rencana pengembangan usaha yang selesai selama proses pendampingan, yakni: dua usaha dibidang fashion (butik pakaian), usaha kerajinan kasur lihab dan usaha kerupukkemplang dan pempek.

Dengan demikian, perubahan yang dialami mitra program yakni pedagang UMKM di Pasar Tradisional Sukawinatan selama dan setelah program dikatakan cukup signifikan. Sedangkan kendala yang dihadapi di lapangan saat pelaksanaan program adalah saat penyampaian materi yang menggunakan istilah-istilah, peserta merasa kesulitan saat menyebutkan atau mengingatnya. Oleh karena itu, narasumber dari tim pelaksana menggunakan kata lain sebagai pengganti dari istilah-istilah tersebut. Kendala tersebut tidak berpengaruh berarti atas tingkat capaian pelaksanaan program. Efektivitas metode pendampingan, monotoring dan evaluasi pelaksanaan program dinilai telah cukup efektif. Hanya saja waktu pelaksanaan program selama 5 bulan dirasakan belum memadai. Oleh karena belum terlihat hasil dari 4 proposal yang bakal diajukan ke pihak bank, apakah didanai ataukah tidak, akan tetapi setidaknya program ini telah memberikan kontribusi kepada pihak mitra sesuai dengan tujuan program.

\section{E. PENUTUP}

Kegiatan pelatihan dan pendampingan pembuatan proposal pengajuan kredit bank bagi para pedagang yang juga sekaligus pelaku atau pemilik UMKM Pasar Tradisional Sukawinatan dilaksanakan sesuai dengan apa yang diharapkan. Hal ini dapat dilihat dari respon positif dari peserta pelatihan dengan pertanyaan dan praktik serta pendampingan pembuatan proposal kredit bank yang telah dilakukan, dimana para peserta justru masih mengharapkan untuk mendapatkan materi lanjutan yang lebih detai serta harapan mereka agar pelatihan lanjutan dapat dilaksanakan misalnya dengan melakukan penilaian kelayakan atas proposal kredit bank yang telah mereka buat. Diharapkan ke depan kegiatan pelatihan dan pendampingan serupa dapat diselenggarakan lagi dalam rangka meningkatkan pengetahuan dan keterampilan para pedagang yang juga sekaligus pelaku atau pemilik UMKM dalam menyusun proposal pengajuan kredit guna mengakses kredit di lembaga perbankan maupun lembaga keuangan lainnya. Peran pihak perbankan pun dituntut dan diharapkan dalam meningkatkan literasi keuangan pada masyarakat dan sosialisasi tentang kredit UMKM yang mereka sediakan. Dengan proposal yang baik, diharapkan lembaga perbankan dan lembaga keuangan dapat merespon secara positif, tentunya kredit yang berhasil diperoleh oleh para pelaku nantinya dapat dimanfaatkan secara bijak untuk meningkatkan usahanya menjadi lebih maju. 


\section{BIBLIOGRAFI}

Firdaus, Rachmat dan Maya, Ariyanti. 2009. Manajemen Perkreditan Bank Umum: Teori, Masalah, Kebijakan dan Aplikasi Lengkap dengan Analisis Kredit. Alfabeta: Bandung.

Firdaus, Rahmat. 2009. Manajemen Perkreditan Bank Umum. Penerbit: Alfabeta, Bandung.

Hasibuan S.P,Malayu. 2008. Dasar-dasar Perbankan. PT. Grafindo: Jakarta.

Hasibuan, Malayu S.P. 2008. Manajemen Sumber Daya Manusia. Cetakan ke-11. Jakarta: PT.Bumi Aksara.

Ikatan Akuntan Indonesia, Standart Akuntansi Keuangan 2004, Penerbit Salemba Empat, Jakarta.

Jopie, Jusuf. 2003. Kiat Jitu Memperoleh Kredit Bank, PT. Elex Media Komputindo Kelompok Gramedia, Jakarta.

Kasmir, 2001. Bank dan Lembaga Keuangan lainnya. Edisis revisi. Jakarta: PT Raja Grafindo Persada.

Kasmir. 2001. Manajemen Perbankan. Jakarta: Raja Grafindo Persada.

Kasmir. 2002. Bank dan Lembaga Keuangan Lainnya. Edisi Revisi 2002. PT. Raja Grafindo Persada: Jakarta.

Thomas, Suyatno, 2007. Kelembagaan Perbankan. Jakarta : PT. Gramedia Pustaka Utama.

Tristiarto, Yoko; Agus Kusmana; dan Tri Siswantini. 2017. Pelatihan dan Pendampingan Penyusunan Proposal Pengajuan Kredit Bank Bagi Kelompok Usaha Perikanan di Wilayah Kelurahan Rangkapan Jaya Baru. Bina Widya, Volume 26 Nomer 2, Edisi Mei 2015. 95-100.

\section{Peraturan Perundang-undangan}

Undang-Undang No. 10/1998 tentang kredit

Bank Indonesia. 1998. Undang-Undang Nomor 10 Tahun 1998 tentang Perubahan Undang-Undang No. 7 Tahun 1992 tentang Perbankan. Jakarta: Gramedia Bank Indonesia, 1998, UU No. 10 tahun 1998, tentang perubahan terhadap UU No. 7 tahun 1992, Jakarta.

Undang-Undang No. 20 tahun 2008 tentang UMKM. 